\title{
Творча спаАщина Михайла Врубеля в музеях України
}

\author{
ЄBГEH IГНАTOB
}

\begin{abstract}
Анотація. У статті представлені результати комплексного дослідження творчого спадку Михайла Врубеля на основі фондів та збірок українських музеїв. ЗАійснена спроба охарактеризувати основні особливості київського періоду творчості видатного художника кінця XIX - початку XX століття, проаналізовані кцючові роботи, створені на території України, та їх значення у хуАожньому доробку митця. Вказано на необхіАність грунтовного вивчення національної культурної спадщини як одного 3 комунікативних засобів в умовах інтенсивної культурної політики України.

Ключові слова: творчість Михайла Врубеля, живопис, творча спадщина, графіка, ескіз.
\end{abstract}

Постановка пробцеми. В історії української хуАожньої культури кінця XIX - початку XX століття постать Михайла Врубемя (1856-1910)? живописця, реставратора, графіка, і^юстратора, скуцьптора та сценографа, чия творчість стоїть біля витоків не одного визначеного напрямку, а практично всіх авангардних пошуків мистецтва ХХ ст., посіАає особливе місце. Його творчість заслужено внесена до скарбниці шедеврів світового мистецтва, і велика колекція творів зберігається саме на території України (Ае він кілька років жив та працював), а саме в Націонацьному музеї «Київська картинна галерея» (Аалі - НМККГ) та ОАеському художньому музеї, Горлівському художньому музеї. Стіни Кирилівської церкви (Церква святих Кирила та Афанасія Олександрійських) та Воло-
Перед тим, що Врубель та йому подібні відкривають людству раз у століття, я вмію лише тремтіти.

Тих світів, які бачияи вони, ми не бачимо.

Омександр Бмок

Аимирського собору прикрашають його монументальними розписами та орнаментами, а також реставраційні роботи Врубемя знаходяться у Софійському соборі.

Художник за все життя бував в Україні неодноразово: закінчив юридичний факультет Рішельєвської гімназії в ОАесі, паралельно вчився у рисувальній школі Спілки образотворчих мистецтв і музики у 1870 та 1872 роках, бував у Харкові на гастроцях Аружини та неоАноразово гостив У родини в Севастополі. Втім, саме в Києві, куди художник приїхав 1884 р. Аля реставрації старих та створення нових монументальних розписів у Кирилівській церкві, почався його самостійний творчий шиях. Саме у Києві він сформував свій стиль, визначив вАасний шАях в мистецтві, створив єАині за життя 
сакральні монументальні роботи - розписи КириАівської церкви, Софійського та Володимирського соборів. За різними Ажерелами, творчий спаАок Врубеля, що зберігається на території України, налічує понад 200 творів.

Системне АосліАження фонАів та збірок українських музейних колекцій, в тому числі і творчого Аоробку видатного російського митця Михайма Врубемя, обумовлене необхіАністю грунтовного вивчення національної культурної спадщини, аАже проблема дослідження та збереження культурного спадку на державному рівні набуває першочергового значення в умовах інтенсивної культурної політики України. Образ сучасної України на загальносвітовому культурному рівні в ході переосмислення національних надбань та поступового входження у загацьномистецький контекст поступово стає цілісним завАяки дослідженню набутків українських митців та вивченню зібрань українських колекціонерів в українських музеях тощо.

У зв'язку з недостатньою вивченістю колекцій українських музеїв, та й усієї культурної спаАщини, сьогодні зростає нагальна потреба у вирішенні актуальних задач систематизації наявного теоретичного і практичного матеріалу, у вдосконаменні діючих та розробці нових принципів і метоАів формування загацьноукраїнського культурномистецького фонау, що сприятимуть піАвищенню культурного рівня країни у світовому культурному середовищі.

Аналіз останніх досліджень і публікацій. Багатогранність таланту, широкі відомості про особисте життя, які знаходимо у згадках сучасників $[3 ; 11]$ і самого Михайла Врубеля, а також універсальність його творчої натури широко АосліАжена у різних сферах мистецтвознавчої науки.

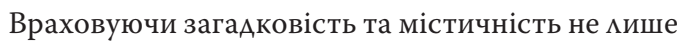
його творчості, а й способу життя, АосліАники А. Коган [10], Н. Амитрієва [6] та інші часом акцентують увагу саме на цьому аспекті, подеку-

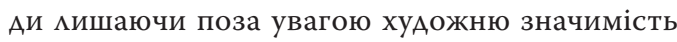
його творів. А. Коган у монографії «Михаим Врубель» аналізує художній спадок художника, широко залучаючи різноманітні архівні матеріали,
Аокументи, спогади сучасників тощо, відтворюючи Аіяльність митця на широкому тлі суспільно-політичного та Аітературно-художного життя кінця XIX - початку XX століття [10]. Письменниця В. Аомітеєва у роботі «Врубель. Біографії та мемуари» образно вибудовує біографію митця, «спрямованого "будити Аушу" втіленнями краси і таємниці» [7]. Грунтовним досліАженням творчості художника $є$ монографія М. Германа «Михаим Врубель» [4], Ае наразі вказується, що сувора Ао художника Аоля Аишила нащадкам вельми скупий Аоробок, зазначаючи, що й він «настільки значний та Аовговічний, передусім тому, що звернений у майбутнє» [4]. Спогади про сучасників та особиста переписка завжди стають Ажерелом інформації про образ художника. НаприклаА, в збірці «Константин Коровин вспоминает...» [11] у повному обсязі представлена Аітературна спадщина виАатного російського художника Коровіна, а саме його спогади про життя, сучасників, у тому числі про Михайла Врубеля. А збірка «Врубель. Переписка. Воспоминания о художнике» [3] містить кистування з рідними, Аружиною Н. Забелою-Врубель, митцями та хуАожніми Аіячами I. Остроуховим, В. Серовим, С. Мамонтовим тощо, а також спогаАи про Врубеля його сестри та Аружини, художників М. Мурашка, М. Нестерова та ін.

Важливим Аля вітчизняної мистецтвознавчої Аітератури стало АосліАження історика I. МаргоАіної «Ангели Врубеля» [13], що вийшло Аруком 2012 року. Це перше в Україні видання, що Аетально розповіАає про роботу митця наА розписами Свято-Кирилівської церкви у Києві та пропонує їх розширену мистецьку характеристику.

Незважаючи на те, що життя і творчість ВрубеАя описані у численних наукових та науково-попуАярних виАаннях, Ао сьогоАні системні досліАження фондів та збірок українських музейних колекцій, обумовлені необхідністю грунтовного вивчення національної культурної спадщини, Аещо обходять творчий Аоробок Михайла Врубеля, який зберігається в українських музеях, що і становить мету пропонованого дослідження. 
Основні результати Аослідження. Художник Михайло Врубель жив та працював в Києві п'ять років (з 1884 по 1889) на запрошення професора ААріана Прахова Аля роботи наА іконостасом взятої ним піА реставрацію Кирилівської церкви. Цей київський період АосліАники називають значним і найпліАнішим у його творчості, аАже саме цього часу Врубель створює оАну з найвідоміших картин «Аівчинка на тАі персиАського кимима» (1886, зібрання НМККГ), створив мегенАарні іконні образи Афанасія, Богоматері, Христа та Кирила Аля мармурового іконостасу Кирилівської церкви, а також стінні розписи в ній та багато іншого. Саме в Києві Врубель починає працювати над своїм найвідомішим художнім образом («Голова Аемона», ілюстрація Ао поеми М. Аермонтова, 1890-1891, зібрання НМККГ).

Твори Михайла Врубеля в Україні розташовані у зібраннях музейних колекцій Національного музею «Київська картинна галерея», ОАеського художнього музею, ГорАівського художнього музею, Кирилівської церкви та Володимирського собору в Києві, а також його надзвичайно майстерні реставраційні роботи можна побачити в купо$\Lambda$ і Софійського собору.

У Національному музеї «Київська картинна гамерея» зберігається одна з найбільших у світі комекція творів Врубеля, унікальна з точки зору повноцінності зібраних в ній робіт київського періоАу. Унікальна колекція містить широко відомі твори, багаточисельні замальовки з натури, начерки та ескізи, а також показує найбільш значні тематичні пласти творчості майстра, які можна умов-

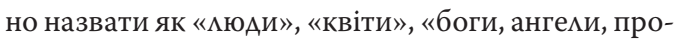
роки» (сакральна тематика). НеобхіАно зазначити, що більша половина робіт митця, що зберігаються в Київському музеї, це замальовки з альбомів художника, ескізи, начерки, сереА яких багато сюжетів з побуту родини ААріана Прахова.

ЕтюА «Натурниця в обстановці Ренесансу» (папір на картоні, акварель, білимо, мак, 1883) був створений Врубелем ще піА час навчання у петербурзькій Академії мистецтв (Ае Врубель займався піА керівництвом професора П. Чистя-

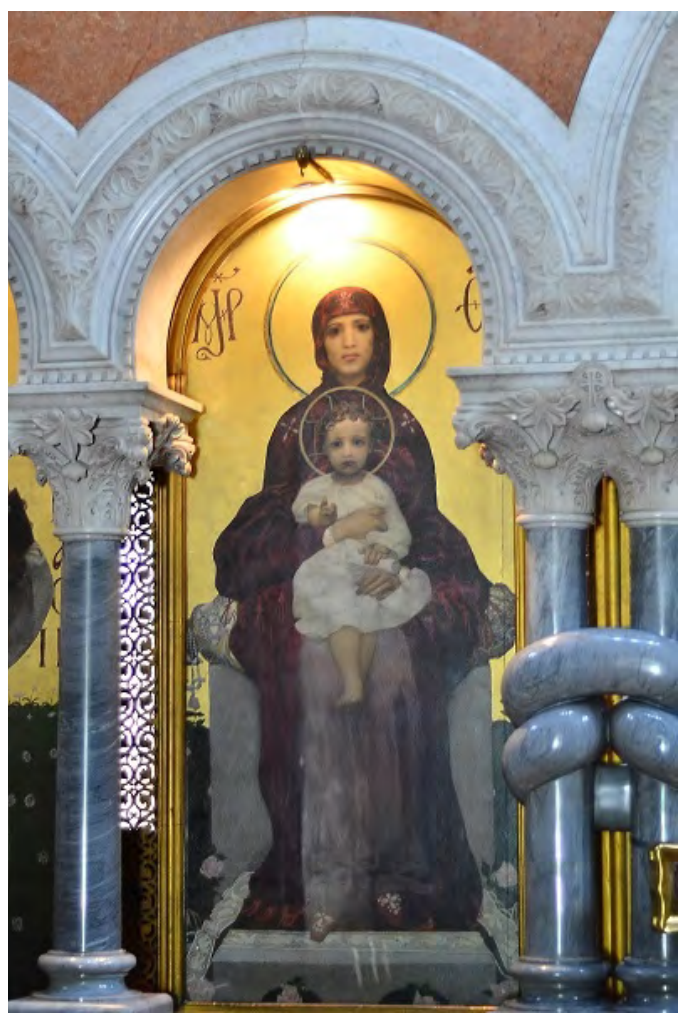

кова) і привезений до Києва як своєрідне свідоцтво наАзвичайної майстерності акварельної техніки Врубеля. У витонченому малюнку проявицося колористичне вміння художника ілюзорно переАати красу зібраних в одному полотні коштовних речей - шовкових мереживних тканин, старовинних мебців, а також Аосконалість оголеного жіночого тіла [2]. Аемонструє бцискуче волоАіння Врубелем акварельною технікою й робота «Східна казка» (папір на картоні, акварель, білимо, графітний олівець, мак, колаж, 1886). Романтичне захоплення художника Сходом особливо яскраво проявилось саме в цій, невеликій за розміром, акварелі. Ювелірна вишуканість, багатство колористичної гамми сприяють створенню таємничої казкової атмосфери та екзотичної пишності східного побуту.

В Київському музеї зберігається і одна з найкращих робіт Врубеля - перший його портрет напи- 
саний омійними фарбами 3 натури - «Аівчинка на тлі персиАського килима», полотно, олія, 1886). Художник зобразив тринадцятирічну доньку власника київської позикової каси Маню Аахнович. Тендітна Аівчинка з блідим обличчям і великими темними сумними очима оточена Аорогоцінними килимами, шовками та прикрасами, сама схожа на коштовну мяльку, загублену сереА речей. У роботі відобразилась пристрасть Врубеля до тонких нюансів кольору і переливів каміння, блиску метамів. Але вся ця розкіш не мишила зображений образ АюАяності - iї живі риси та неприкритий сум гостро виступають на фоні розкішного тла. Михайло Врубель створив таким чином поетичний образ, сповнений загадковості, чарівності та краси [2]. Живописна поверхня полотна мерехтить поАібно Ао блиску Аорогоцінного каміння та мозаїчної смальти. У цій роботі художник вперше знайшов свій колористичний тембр - «звучання» густих, наче сутінкових холодних тонів, намагаючись винайти нові прийоми олійного живопису, не просто зімітувати мозаїку, а й перетворити зображення на коштовність, яка мерехтить із глибини полотна чистим повнозвучним кольором [5].

В Київському музеї також преАставлена одна 3 найбільших колекцій етюдів та квіткових композицій Михайла Врубеля. Розквіт цього жанру в творчості художника прийшовся саме на київський період. Сам мистець, за згадками сучасників, особливого значення таким роботам не надавав, вважаючи їх «прохідними», однак ці махенькі шеАеври сьогодні скмаАають широкий пласт його творчого Аоробку. Практичним піАтверАженням промовистого висловлювання Врубеля про орнаментальність може слугувати його акварель «Шиповник» (папір, акварель, 1884, зібрання НМККГ). ПіА «орнаментальністю» він розумів такий метоА роботи, коли художник, вигаАуючи або малюючи

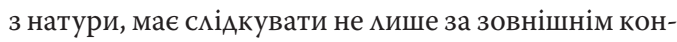
туром преАмету, його абрисом, а й за обрисами самого фону, пікцуватися про його зв'язок з основним предметом зображення, щоб всі елементи композиції були міцно пов'язані між собою. Сам Врубель завжАи прагнув проникнути «вглиб» предмету, зо- бразити його в Аекількох планах, пов'язаних між собою [5]. У своїх малюнках квітів з натури Врубель навмисно будує форму на оптичній наближеності та деталізації, а не на просторовій відАаменості та узагальненні. Це надає його зображенням особливої інтимності.

ЕтюАИ квітів, Ао зображення яких неодноразово звертався художник, представ яють його власний світ піАнесеної, натхненної краси. У мінливих, хитких формах азалій, ірисів, орхідей, шипшини вражає конструктивна чіткість та структурність. $\mathrm{O}_{\mathrm{A}}$ нак аналітичність Врубеля не заважала йому віАчувати і передавати поезію життя, адже «амгебра» i «гармонія» в його творах нерозривно пов'язані. Так, ніжність, прозорість і свіжість, що випромінює «Біла азалія» (етюА, графічний олівець, папір, акварель, 1886-1887, зібрання НМККГ) - результат проникнення в «архітектуру» квітки, скрупуАьозного аналізу характерних ознак графічними засобами. Кожен штрих малюнку, Аягаючи у певну площину, маконічно проявляє експресивну й Аивовижно активну художню форму [2].

ОАнією з головних тем творчості Врубеля $є$ біблійні та євангельські образи. Образи Богородиці, Ісуса, янголів, архангелів, Аемонів супровоАжували художника протягом усього його творчого життя, відображаючи внутрішній стан митця та красу світу. У Київському музеї зберігається ціка галерея потужних і надзвичайно виразних художніх образів, що виявляють у повному обсязі та розмаїтті цей тематичний пласт творчого Аоробку митця.

Вищим досягненням Михайла Врубеля київського періоду його творчості стали акварельні ескізи до розписів Володимирського собору. «Митець написав ескізи до розпису вже збудованого Володимирського собору, але так сталося, що вони не прикрасили собор. Це махи бути великі композиції - «Янгол $з$ кадилом і свічкою» та «Плач надгробний». Нині ці ескізи збережені у Музеї російського мистецтва в Києві» [13].

В експозиції Музею представлені чотири варіанти «надгробного плачу» (1887, папір, графітний олівець, акварель). У Ааних ескізах майстер 


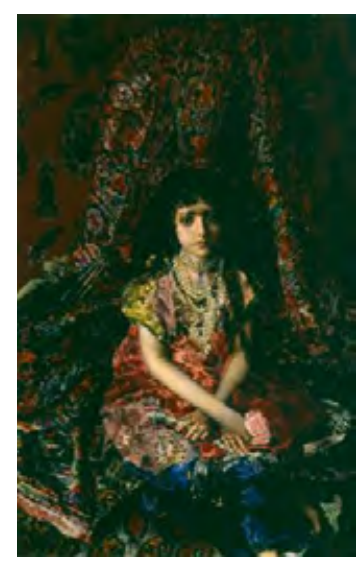

Аемонструє власну Араматичну і разом з тим монументальну розробку траАиційного біблійного сюжету, в повній мірі відчуваючи художню істину Аавньоруського і візантійського мистецтва, розуміючи його красу і натхненність. У всіх варіантах «наАгробного плачу» художник віАтворює німий Аіалог Марії та Христа, візуацізуючи наАзвичайно тонку красу мюАського горя.

Ще оАин неперевершений ескіз Аля оформиення собору - «Янгол з каАилом та свічкою» (папір, акварель, графітний омівець, 1887). Сучасники вважали, що це автопортретне зображення самого художника. Врубель створив наАзвичайно натхненний образ Божого посланця, який скоріше нагаАує італійського юнака $з$ картин майстрів епохи бароко. Втім, його неземна сутність віАображена у відчуженому погляді, фантазійному тонкому і багатобарвному вбранні, а крима зображені настільки тонко, що мише вгадуються.

Ескізи розписів Володимирського собору є кульмінацією київського періоду Врубеля (1887, акварель і графітний омівець, переважно НМККГ); з часів Аревнього іконопису російський живопис не знав комьорових гам такої сими узагацьнення і впливу. НеАивно, що ці ескізи збентежили офіційну церковну комісію і залишилися не зАійсненими у великому масштабі, на стіні, адже вони настікьки вибивацись із загацьного ритму робіт інших художників, які працювали наА оформиенням собору.

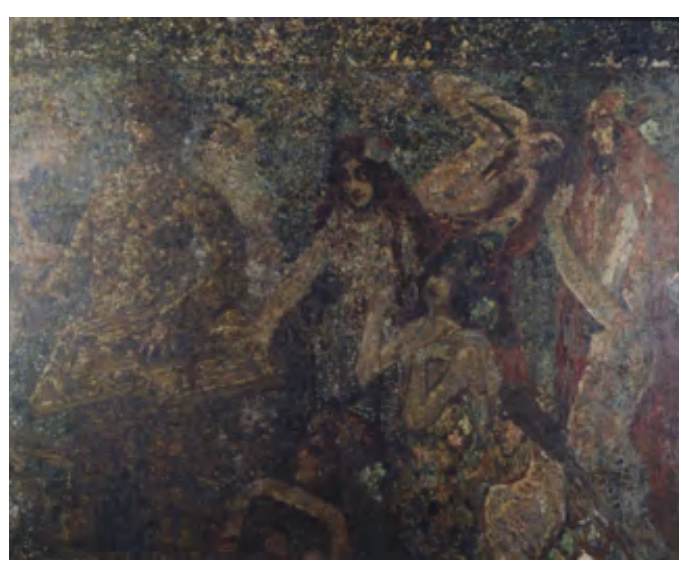

Ще оАин період творчості Михайла Врубеля пов'язаний з ОАесою, Ае він прожив майже п'ять гімназійних років, вчився у школі малювання, а пізніше, вже сталим художником, почав роботу наА віАомим «Аемоном». Зі своїм товаришем В. Сєровим Врубель планував відкрити там приватну хуАожню школу на кшталт французьких шкіл малювання, а також гостював у батьків, які прожили в цьому місті майже 10 років [1].

Так, у зібранні ОАеського художнього музею сьогодні експонується Аекілька відомих робіт Михайла Врубеля: Ава живописних полотна («Вацькірія» (1899), «Болотні вогні» (1890), Ава малюнки («Родина Я. Тарновського за карточним сто-

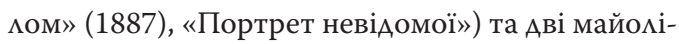
ки («Волхова», «Жінка в кокошнику»).

Полотно «Валькірія» (полотно, олія, 1899, зібрання ОХМ) потрапимо до колекції Музею 1926 року із зібрання М. Брайкевича (так само, як і робота «Болотні вогні»). В образі Валькірії було візуалізовано княгиню Марію Тенишеву — відому меценатку та колекціонерку, в садибі якої Врубель Аеякий час гостював разом зі своєю Аружиною. Художник зобразив витончену та задумииву жінку у розкішному вбранні. Врубель практично написав портрет самої Марії у вигляді скандинавської богині Валькірії, але в художника, за великим рахунком і власним віАчуттям, не стояма задача подібності з оригіналом. Риси ії обличчя трохи перебільшені: строго стиснуті тонкі губи, овацьне обличчя, розши- 
рені очі - «Валькірія» несе в собі деякі демонічні мотиви, властиві неповторній творчості митця.

В музейній колекції ОАеського художнього музею зберігаються ще Ава малюнки: «Родина Я. Тарновського за карточним столом» (1887) та «Портрет невідомої», а також Аві майоліки: «Волхова» за мотивами опери Римського-Корсакова «Садко» та «Жінка в кокошнику», яка потрапила до музею із зібрання А. Русова, - створені в період захоплення Врубелем театром та сценографією.

На території України зберігаються також Аві Ауже цікаві роботи художника: живописне полотно «Садко» (1898) та графічний «Портрет Аружини Аікаря Усольцева» (1861). Ці твори знаходяться в ко-

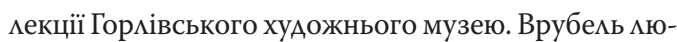
бив експериментувати з живописними техніками, «СаАко» - яскравий прикмаА таких експериментів. Художник в процесі написання Аодав до олійних фарб цинк з метою надати кольору більшу насиченість. Характерний врубелівський мазок, стимізований піА візантійську мозаїку, з вкрапленнями шматочків фольги по всій площині картини, мав незвичний Аекоративний блиск. Існують свідчення сучасників художника про те, що картина блищама та переливалася, мов була скмадена з найдрібніших дорогоцінних часточок.

Та, нажаль, митець не врахував того, що з часом цинкова фарба неодмінно та незворотньо побцякне. Можливо, він розраховував на короткотривамий ефект віА «СаАко» і тому не переймався Аовговічністю роботи. А^е ймовірніше, це був чистий експеримент, результатів якого ніхто, вкАючаючи автора, передбачити не міг.

Висновки. Михайло Врубель - основоположник символізму та модерну в російському мистецтві, якого називають одним із найвизначніших митців свого часу, часу межі XIX та XX століття, часу великих культурно-соціальних змін та зрушень, цікавих АосліАжень, віАкриттів та Аосягнень. 3 Україною пов'язаний один із найбільш пліАних та цікавих за своєю різноманітністю та усвідомиеністю періодів творчості Михайла Врубемя. В українських музеях віА часу перебування художника в Україні (аАже й тоді його роботи потрапляли в збірки відомих колекціонерів) дотепер зберігається велика кількість (близько 200) його визначних творів, як станкового, так і монументального живопису, а також майоліки.

Спадщина Михайла Врубеля давно вже стала Аорогоцінним надбанням світової культури. СереА його творів - портрети, жанрові картини, декоративні панно, ілюстрації, ескізи театрацьних завіс, скульптурні твори, проекти будинків, що вражають за розмахом і широтою творчого діапазону.

У Києві, куди Врубель приїхав 1884 року на запрошення відомого історика-мистецтвознавця і археолога А. Прахова Аля участі в реставрації КириАівської церкви, він опиняється в епіцентрі пошуків великого національного стилю: в творах київського періоду, що наразі зберігаються в Київській картинній галереї та ОАеському художньому музеї, розкрився талант колориста та малювальника, в ескізах до розписів Кирилівської церкви та Вомодимирського собору - монументаліста і декоратора (чотири ескізи «Надгробний плач» (1887), «Янгол з кадицом та свічкою» (1887), обидва зібрання КНМРМ), віАбилося прагнення Ао піАнесено-одухотвореного мистецтва, що, за задумом митця, протистоїть «сірій повсякденності».

У київському періоді художник виступив як наАзвичайно обдарований майстер акварельної техніки («Шиповник» (1884), «Біка азалія» (1886-1887), обидва - зібрання НМККГ, «Родина Я. Тарновского за карточним столом» (1887), «Портрет невідомої» (обидва - зібрання ОХМ).

Великий талант молодого художника, колориста і майстра пензмя проявився у вмінні ілюзорно передати красу зібраних до купи коштовних речей - візерункових шовкових тканин, старовинних меблів, а також досконалість оголеного жіночого тіла («Аівчинка на тлі персиАського килима» (1886), «Натурниця в обстановці Ренесансу» (1883), «СхіАна казка» (1886) - зібрання НМККГ, «Валькірія» (1899) та майоліки «Волхова» $\mathrm{i}$ «Жнка в кокошнику» - зібрання ОХМ).

Таким чином, маючи в Україні видатну колекцію робіт Михайла Врубеля, найбільш значного і самобутнього виразника тенденцій символізму 
та модерну в живописі та графіці, і досліАжуючи ïх на рівні державної спадщини, Україна має ве- мичезний потенціал у вирішенні визначних питань кумьтурної політики.

\section{Мітература}

1. Алпатов М. Живописное мастерство Врубеля. М.: Аира, 2000. 232 с.

2. Врубель M. URL: http://www.kmrm.com.ua/rus/kolekciya/personalii/1144.html (дата звернення 28.08.2018)

3. Врубель. Переписка. Воспоминания о художнике. М.: Искусство, 1963.

4. Герман М. Михаил Врубель. 1856-1910. СПб.: Аврора, 1996. 159 с.

5. Аевочка на фоне персиАского ковра - 1886. Михаил Врубель. Творчество URL: http://www.filoli.ru/ artists/077-wrobel/wrobel-devochka.php (Аата звернення 28.08.2018)

6. Амитриева Н. Михаил Врубель. Жизнь и творчество. М.: Искусство, 1984.

7. Аомитеева В. Врубель. Биографии и мемуары. М.: Молодая гвардия, 2014.

8. Аьяченко С. В образе святого // Новый Фаворит. 2010. № 1 (40). С. 6-9.

9. Климов П. Михаил Врубель. Альбом. М.: Арт-Родник, 2001.

10. Коган А. Врубель. М.: Искусство, 1980.

11. Константин Коровин вспоминает... Сборник. М.: Изобразительное искусство, 1990.

12. М. Врубель - характеристика творчества, произведения // Культура - здесь и сейчас. URL: http://velikayakultura.ru/russkaya-zhivopis/m-a-vrubel-harakteristika-tvorchestva-proizvedeniya (Аата звернення 28.08.2018)

13. Марголіна I. Ангели Врубеля. К.: АибіАь, 2012. 144 с.

14. Символизм творчества М. Врубеля в современном мире как объект анализа, изучения и вдохновения. URL: http://www.microanswers.ru/article/simvolizm-tvorchestva-m-a-vrybelja.html (дата звернення 28.08.2018).

15. Скоробогачева $\Lambda$. Михаил Врубель. М.: Арт-Родник, 2010.

16. Циба Г. Врубель и Киев. URL: http://artukraine.com.ua/a/vrubel-i-kiev/\#.W4KjrOgzZPY (10.10.2011) (Аата звернення 28.08.2018).

\section{References}

1. Alpatov M. Zhivopisnoe masterstvo Vrubelya. M.: Lira, 2000. $232 \mathrm{s.}$

2. Vrubel M. URL: http://www.kmrm.com.ua/rus/kolekciya/personalii/1144.html (data zvernennya 28.08.2018)

3. Vrubel. Perepiska. Vospominaniya o hudozhnike. M.: Iskusstvo, 1963.

4. German M. Mihail Vrubel. 1856-1910. SPb.: Avrora, 1996. 159 s.

5. Devochka na fone persidskogo kovra - 1886. Mihail Vrubel. Tvorchestvo URL: http://www.filoli.ru/ artists/077-wrobel/wrobel-devochka.php (data zvernennya 28.08.2018)

6. Dmitrieva N. Mihail Vrubel. Zhizn i tvorchestvo. M.: Iskusstvo, 1984.

7. Domiteeva V. Vrubel. Biografii i memuaryi. M.: Molodaya gvardiya, 2014.

8. Dyachenko S. V obraze svyatogo // Novyiy Favorit. 2010. \# 1 (40). S. 6-9.

9. Klimov P. Mihail Vrubel. Albom. M.: Art-Rodnik, 2001.

10. Kogan D. Vrubel. M.: Iskusstvo, 1980.

11. Konstantin Korovin vspominaet... Sbornik. M.: Izobrazitelnoe iskusstvo, 1990. 
12. M. Vrubel - harakteristika tvorchestva, proizvedeniya // Kultura - zdes i seychas. URL: http:// velikayakultura.ru/russkaya-zhivopis/m-a-vrubel-harakteristika-tvorchestva-proizvedeniya (data zvernennya 28.08.2018)

13. Margolina I. Angeli Vrubelya. K.: LibId, 2012. $144 \mathrm{~s}$.

14. Simvolizm tvorchestva M. Vrubelya v sovremennom mire kak ob`ekt analiza, izucheniya i vdohnoveniya. URL: http://www.microanswers.ru/article/simvolizm-tvorchestva-m-a-vrybelja.html (data zvernennya 28.08.2018).

15. Skorobogacheva L. Mihail Vrubel. M.: Art-Rodnik, 2010.

16. Tsiba G. Vrubel i Kiev. URL: http://artukraine.com.ua/a/vrubel-i-kiev/\#.W4KjrOgzZPY (10.10.2011)

(data zvernennya 28.08.2018).

\section{Игнатов E. E. Творческое наследие Михаика Врубеля в музеях Украины}

Аннотация. В статье преАставлены результаты комплексного изучения творческого наследия Михаила Врубеля на основе фондов и собраний украинских музеев. Осуществлена попытка охарактеризовать основные особенности киевского периода творчества выдающегося художника конца XIX - начала XX века, проанализированы кмючевые работы, созданные на территории Украины, и их значение в художественном наследии художника. Подчеркнута необходимость тщательного изучения национального культурного наследия как одного из коммуникативных среАств в условиях интенсивной культурной политики Украины.

Ключевые слова: творчество Михаила Врубеля, живопись, творческое наследие, графика, эскиз.

\section{Ignatov E. E. Mikhail Vrubel/s creative heritage in museums of Ukraine}

Abstract. The article presents the results of a comprehensive research of the creative heritage of Mikhail Vrubel, that based in the funds and collections Ukrainian museums. An attempt was made to characterize the main features of «Kyiv» period the artist of the late XIX - early XX century, analyzed important works that created in Ukraine, and their importance in the artistic works of the artist. The necessity of thorough study of the national cultural heritage as one of the communicative means in the conditions of intensive cultural policy of Ukraine is indicated.

Keywords: creativity of Mikhail Vrubel, painting, creative heritage, graphics, sketch. 